\section{NEW RECORD OF A RARE BARBIN NEOLISSOCHILUS WYNAADENSIS (DAY) FROM ABBY FALLS, KARNATAKA}

\section{Arunachalam, M. Muralidharan, P. Sivakumar, R. Soranam and M. Murugan}

Sri Paramakalyani Centre for Environmental Sciences, Manonmaniam Sundaranar University, Alwarkurichi, Tamil Nadu 627412, India

Email: tvl_arunces@sancharnet.in; arunacm@gmail.com web supplement

Neolissochilus wynaadensis (Day) a rare and endemic barbin was described by Day (1877) from Vithry, Wynaad, Kerala and since its description it has been considered endemic to Wynaad part of Kerala (Menon, 1999).

Easa and Shaji (1997) reported this species as rare and confined its distribution to Kerala part of Nilgiri Biosphere Reserve, from where few streams of river Cauvery take their origin and based on this, Jayaram (1999) presumed the occurrence of this species likely to be in headwaters of Cauveri in Karnataka also. Recently Gopi (2000) reported the occurrence of this species from Vatapoil in Wynaad district based on the specimens available from the collection of the Zoological Survey of India/Western Regional Station, Kozhikode. Also it has been reported from Kalindhi river, a tributary of Kabini in Wynaad (Kurup et al., 2002). However, there is no description since Day (1877) and no report is available on the existence of this species beyond Wynaad part in the state of Kerala. Here we report this species collected from a small stream $\left(11^{0} 29^{\prime} 98.2^{\prime \prime} \mathrm{N}-75^{\circ} 43^{\prime} 0.08^{\prime \prime} \mathrm{E}\right)$ below the Abby falls a minor tributary of Cauvery, $5 \mathrm{~km}$ from Madikeri town of Kodagu district, Karnataka. The characteristics of the specimen in the present collection is found to be the same as per original description by Day (1877) in morphological and meristic counts. This note forms an extension of its range to Karnataka part of Western Ghats.

\section{Materials ANd Methods}

Fishes were collected using cast nets. Specimens were preserved in $10 \%$ formalin and kept in the Natural History Museum of Manonmanium Sundaranar University, Alwarkurichi. Methods used for counts and measurements follow those of Hubbs and Lagler (1958). All morphometric measurements were made in a standard fashion using digital calipers to $0.1 \mathrm{~mm}$. Comparison materials were from registered collection of Zoological Survey of India, Calcutta and ZSI/WRS, Western Regional Station, Kozhikode.

\section{Neolissochilus Rainboth}

Neolissochilus Rainboth, 1985, Beaufortia, 35(3), pp. 26 (type species, Barbus stracheyi Day, 1871, by original description).

\section{Materials examined}

Barbus stracheyi Day, 1871: 307 (type locality: Akyab and Moulemein). Type and subsequently illustrated specimen, ZSI 2175, from Moulemein, examined in Calcutta.
Neolissochilus wynaadensis, three specimens, 02.iii.1994, Vattapoil, Wynaad, Kerala, coll Dr. P.M. Sureshan, ZSI/WRS Calicut Reg. No. 6868.

\section{DESCRIPTION}

D iv 9 , A iii 5, P i 15, V i 8. Body elongate, its depth about $22 \%$ SL. Dorsal margin strongly convex predorsally, in lateral aspect with curvature much more pronounced than that of ventral margin. Dorsal fin origin two scales (one large scale and one small scale) prior to pelvic fin origin. Predorsal profile smoothly rounded with no concavity at nape. Trunk and peduncle compressed. Peduncle moderately shallow, its shallowest region, about 1.6 times in its length (the distance from the anal fin insertion to caudal fin base). Mouth sub terminal with subequal lower jaw. Lower jaw keratinous but not sharp.

Dorsal spine weak, with almost no posterior curvature. Fin moderately high with a concave distal margin. Last unbranched ray smooth and not strong $(16.1 \% \mathrm{SL})$. Anal fin deep $(14.3 \%$ $\mathrm{SL}$ ), extending up to four scales anterior to the base of the caudal fin. Last unbranched ray longest, margin of fin pointed and not falcate tip. Pelvic fin moderate, its length $15.9 \%$ of SL extending to three scale rows before vent, and the first branched ray produced. Distal margin of branched rays nearly straight when the fin is held erect. Pectoral fin extending to third scale row before pelvic fin, its length $20.4 \%$ of SL, with tip slightly produced and distal margin nearly straight; caudal fin moderately forked.

Head length $27.7 \%$ of SL. Head depth at pupil and head depth at occiput $51.6 \% \mathrm{HL}$ and $65.1 \% \mathrm{HL}$, respectively. Head width at the pre opercle narrow, $43.8 \%$ of HL and interorbital width moderate, $29.7 \%$ of HL, head width 2.79 times of the eye diameter. Eyes small, width of orbit $16.3 \%$ of HL, the pupil situated in the anterior upper part of head. Mouth sub terminal with lower jaw seemingly sub equal when mouth is closed. Snout moderately long, $33.8 \%$ of HL. Lower lips slightly reflected at median, though no distinct notch is present. A groove separating the lower lip from the mandibular sheath extends to the angle of the gape. A similar groove on the upper jaw extends more than the distance from the median to the jaw angle. Barbels short.

\section{Scale count}

Lateral line with 28 scales, predorsal scales 11, upper transverse scales four, scale rows from lateral line to pelvic insertion four, circumferential scales 18 , circumpeduncular scales 12 , anal scale rows two.

\section{Colouration}

In live condition, dorsum dark, second and third rows from the predorsal scale row pink and next two rows including the lateral line scale row bluish in colour with a band like appearance. Belly whitish with dull yellow. Fins are reddish with distal margin black. Cheek pigmented. In formalin preserved specimens, body appears darker from dorsal region up to lateral line scales and belly greyish.

${ }^{w}$ see Image $1 \& 2$ in the web supplement at www.zooreach.org 
Table 1. Comparison of meristic characters of Neolissochilus wynaadensis from Wynaad and Abby falls

\begin{tabular}{|c|c|c|c|}
\hline \multirow[t]{2}{*}{$\begin{array}{l}\text { Morphometric } \\
\text { Characters }\end{array}$} & \multicolumn{2}{|c|}{$\begin{array}{l}\text { Vattapoil }(n=3) \\
\text { ZSI/WRS Kozhikode } \\
\text { Reg No. } 6868\end{array}$} & \multirow[t]{2}{*}{$\begin{array}{l}\text { Abby falls } \\
(n=1)\end{array}$} \\
\hline & Range & Mean & \\
\hline Total length (mm) & $112.3-137.2$ & 122.9 & 256.7 \\
\hline Standard length $(\mathrm{mm})$ & $85.9-108.6$ & 95.8 & 205.2 \\
\hline \multicolumn{4}{|l|}{$\%$ of $\mathrm{HL}$} \\
\hline Head depth at pupil & $58.7-65.2$ & 62.3 & 51.6 \\
\hline Head depth at occiput & $67.8-71.7$ & 70.3 & 65.1 \\
\hline Snout length & $30.8-35.4$ & 33.4 & 33.8 \\
\hline Prenasal length & $20.9-23.2$ & 22.6 & 19.2 \\
\hline Orbit width & $18.3-23.6$ & 20.6 & 16.3 \\
\hline Interorbital width & $30.4-32.4$ & 31.2 & 29.7 \\
\hline Internasal width & $16.6-22.3$ & 19.7 & 19.0 \\
\hline Head width & $53.6-60.0$ & 55.8 & 43.8 \\
\hline Preoccipital length & $87.4-97.7$ & 92.9 & 97.8 \\
\hline \multicolumn{4}{|l|}{$\%$ of SL } \\
\hline Head length & $25.1-29.5$ & 27.7 & 27.7 \\
\hline Dorsal Spinous ray & $13.9-16.1$ & 14.7 & 16.1 \\
\hline Pectoral fin length & $16.9-19.8$ & 18.3 & 20.4 \\
\hline Pelvic fin length & $13.8-17.0$ & 15.5 & 15.9 \\
\hline Caudal fin length & $27.3-30.0$ & 28.4 & 25.1 \\
\hline Peduncle depth & $9.4-10.0$ & 9.9 & 10.9 \\
\hline Body depth & $22.8-25.0$ & 24.1 & 22.7 \\
\hline Peduncle length & $13.1-17.5$ & 15.5 & 19.0 \\
\hline Predorsal length & $48.1-49.7$ & 48.8 & 49.4 \\
\hline Preanal length & $74.8-77.7$ & 76.9 & 72.5 \\
\hline Prepelvic length & $52.1-55.2$ & 54.5 & 48.9 \\
\hline Prepectoral length & $26.2-32.1$ & 29.5 & 24.4 \\
\hline Postdorsal length & $34.5-39.2$ & 37.3 & 36.7 \\
\hline Occiput to dorsal origin & $24.9-26.1$ & 25.9 & 29.2 \\
\hline Occiput to pectoral insertion & $16.4-19.0$ & 17.5 & 16.1 \\
\hline Dorsal origin to pectoral insertion & $28.2-30.5$ & 29.4 & 30.2 \\
\hline Dorsal origin to anal origin & $33.0-34.3$ & 33.9 & 34.2 \\
\hline
\end{tabular}

\section{Discussion}

Most of the meristic counts and morphometric measurements studied for the specimen from Abby falls are similar to that of the comparative specimen from Vattapoil. Except for few variations in morphometric characters, of which some are close to the range of the measurements in the comparative specimens and others remain slightly distinct outside the range. Variations in characters like the prenasal length and interorbital width are very minute.

Characters like head depth at pupil, head depth at occiput, orbit width, head width, prepelvic length, prepectoral length and occiput to dorsal origin are found to be smaller when compared to the proportion of measurements in the registered specimens.

Among fin characters pectoral fins and caudal fin show changes, the pectoral fins are slightly longer and caudal fin little shorter than the comparative specimens. Variations in morphometric measures may be due to habitat conditions and the size of specimens examined.

\section{REFERENCES}

Day, F. (1875-78). The Fishes of India: Being a Natural History of the Fishes known to inhabit the Seas and Freshwaters of India, Burma and Ceylon. Text and Atlas in 2 parts, London. Indian Reprint by Jagmander Book Agency, New Delhi, 778pp+195pls.
Easa, P.S. and C.P. Shaji (1997). Freshwater fish diversity in Kerala part of the Nilgiri Biosphere Reserve. Current Science 73(2): 180-182. Hubbs, C.L. and K.F. Laglerv (1958). Fishes of great lakes region. Univ. Michigan press, Ann Arbor, 213pp.

Gopi, K.C. (2000). Freshwater Fishes of Kerala state, pp.56-76. In: Ponniah, A.G. and A. Gopalakrishnan (Eds.). Endemic Fish Diversity of Western Ghats. NBFGR-NATP Publication - 1, National Bureau of Fish Genetic Resources, Lucknow, India.

Jayaram, K.C. (1981). The Freshwater Fishes of India, Pakistan, Bangladesh, Burma and Sri Lanka. Handbook, Zoological Survey of India, No. 2 xii+475pp.

Jayaram, K.C. (1999). The Freshwater Fishes of the Indian Region. Narendra Publishing House, Delhi, 551pp.

Kurup, B.M., K.V. Radhakrishnan and T.G. Manojkumar (2002). Biodiversity status of fishes inhabiting rivers of Kerala (South India) with special reference to endemism, threats and conservation measures (unpublished), 36pp.

Menon, A.G.K. (1999). Checklist - Freshwater Fishes of India. Records of Zoological Survey of India, Occasional Paper No. 175. 366pp.

Rainboth, W.J. (1985). Neolissochilus, a new genus of south Asian Cyprinid fishes. Beaufortia 35(3): 25-35.

\section{ACKNOWLEDGEMENTS}

Senior author (M. Arunachalam) is grateful for the financial assistance from NATP under the Mission Mode Programme of "Germplasm Inventory Evaluation and Gene Banking of Freshwater Fishes" (Sanction No. 27 (281/ 98/ NATP/MM - III 18 Dt. 23.12.1999). We also thank Dr. D. Kapoor, Mission Leader and Director and Dr. S.P. Singh, Principal Investigator, Lead Centre, National Bureau of Fish Genetic Resources, Lucknow for the lead role in this programme.

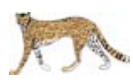

\section{Book Released}

\section{Status of South Asian Non-volant Small Mammals}

Authored by the region's small mammal experts

$$
\begin{gathered}
\text { ISBN 81-88722-11-1 (Paperback); } \\
\text { 81-88722-12-X (CD-Rom) }
\end{gathered}
$$

618 pages of information on 185 species of small mammals (Erinaceomorpha, Lagomorpha,

Pholidota, Rodentia, Scandentia and

Soricomorpha) in South Asia including neverbefore compiled information on distribution, maps, threats, IUCN status at the global, regional as well as individual country level (Bangladesh, Bhutan, India, Nepal, Pakistan and Sri Lanka) based on the Conservation Assessment and Management Plan workshop held in February 2004.

Published by Zoo Outreach Organisation and Wildlife Information \& Liaison Development Society.

Write to ZOO for more information. 